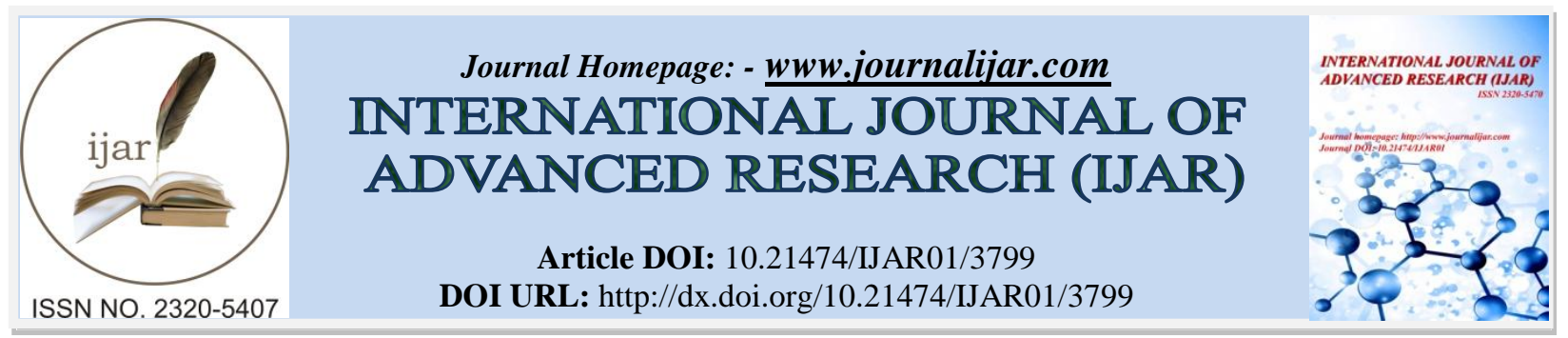

RESEARCH ARTICLE

\title{
ROLE OF USG GUIDED FNAC IN DIAGNOSIS OF INTRA-ABDOMINAL AND INTRAPELVIC MASSES.
}

Dr. Momota Naiding ${ }^{1}$, Dr. Anirban Goswami ${ }^{2}$ and Dr. Shipra Singh ${ }^{2}$,

1. Associate professor, Department of Pathology, Silchar Medical College and Hospital, Silchar, Assam- 788014, India.

2. Post Graduate Student, Department of Pathology, Silchar Medical College and Hospital, Silchar, Assam-788014, India.

\section{Manuscript Info}

Manuscript History

Received: 16 February 2017

Final Accepted: 07 March 2017

Published: April 2017

Key words:-
(..........................

Intra-abdominopelvic, FNAC, USG.

\section{Abstract}

Image guided cytology is emerging as less invasive, cost effective procedure with remarkable sensitivity, specificity and diagnostic yield to enhance the diagnostic accuracy of imaging modalities for deep seated lesion.

Aim: The aim of our study was to analyse the usefulness of ultrasound guided fine needle aspiration cytology in the diagnosis of intraabdominopelvic masses and to assess the cytomorphological features of various lesions with their Age and sex distribution pattern.

Materials and Methods: The study included 57 clinically and radiologically suspected palpable and non-palpable intraabdominopelvic lesions. USG guided FNAC was done in all the nonpalpable lesion and for a few selected palpable lesions. Giemsa's and Papanicolaou's stains were used.

Results: Cases were reported in age range of 2-78 years with a M: F of 1.3:1. There were $37(64.91 \%)$ malignant, $15(26.31 \%)$ benign and 5 $(8.77 \%)$ inconclusive cases. Liver and gallbladder were most common involved sites. This study showed $100 \%$ specificity and $95 \%$ sensitivity for malignant lesions. Diagnostic yield was $91.2 \%$.

Conclusion: USG guided FNA cytology is a simple and safe procedure. It can be utilized as a pre-operative procedure for the management of intra-abdominopelvic lesions.

Copy Right, IJAR, 2017,. All rights reserved.

\section{Introduction:-}

Abdominopelvic masses are mostly deep seated and non-palpable. Due to undetailed margins of these masses it is difficult to assess the size and shape of these lesions. Acceptance of fine needle aspiration cytology as diagnostic procedures prioritize it even above diagnostic laparoscopy in many cases. Most of the malignant lesions usually carries grave prognosis, however accurate diagnosis of cell type involved in causation can prove to be beneficial for institution of therapies improving the prognosis.

For diagnosing malignant ones, FNA cytology is found to be more useful with specificity of $100 \%{ }^{(6)}$ (7). For proper delineation of these masses, FNAC is assisted by various radiological guidance procedure like fluoroscopy, CT, and USG.

Corresponding Author:- Dr. Momota Naiding.

Address:- Associate professor, Department of Pathology, Silchar Medical College and Hospital, Silchar, 
In most of government setups, like ours, due to overburdened surgical units with limited resources and cost effectiveness, for diagnosis of malignancies, CT guided FNAC is not much adopted as compared to USG guided FNAC as diagnostic procedure.

Our objectives were to assess the cytomorphological features, age and sex distribution of the patients with intraabdominal and intrapelvic lesions, to classify the malignant lesions according to their cell type and to evaluate the sensitivity and specificity in malignant lesions.

\section{Material and Methods:-}

This study is conducted in Department of Pathology, Silchar Medical College and Hospital, from Jan 2016 to Dec 2016(12 months). After taking written consent from the patients, aspiration of abdominal and pelvic masses were done, which were referred from various clinical departments for opinion on cytological diagnosis in our Department of cytology.

Intra-abdominal and intra pelvic organs include liver, gall bladder, pancreas, spleen, retroperitoneal organs, ovary, testis and right and left iliac fossa masses. All parietal swellings and prostatic swellings are excluded.

Masses are categorised into palpable and non-palpable ones. Selected lesions are subjected to USG guided aspiration. After marking the puncture site, under all aseptic and antiseptic conditions, a 22-23G needle for superficial lesions and a lumbar puncture needle of the same thickness for deep seated lesions, fitted with a $10 \mathrm{ml}$ syringe, was introduced immediately under radiological guidance and the aspiration was done under negative pressure. A minimum of two to three needle passes was used. The aspirated sample was expelled onto the slides. Each aspirate was smeared on an average of four to five slides, air-dried and stained with Giemsa or it was fixed in 95\% ethanol and stained with Papanicolaou's stain. Special stains were used wherever required.

The FNAC diagnosis was correlated with clinical and radiological information. The smears were classified as benign, malignant, and inconclusive.

\section{Results:-}

In our study period of 1 year, 1708 cases were attended in Department of Cytology. Out of these 170 (10\%) underwent radiology guided FNAC. Of all radiologically analysed lesion, 57 (33.25\%) cases with intra abdominopelvic masses were selected for USG guided FNAC.

32 males and 25 females with male to female ratio of 1.3:1 were included. We had patients from 2 yrs to 78 years old. A majority of the patients i.e. 29 (50.9\%) were in the age group of 41-60 year. (Table:1)

Of 32 lesions in the male patients, a majority were malignant, accounting for 24 (75\%) lesions, 4(12.5\%)lesions were inflammatory lesions, and $2(6.25 \%)$ lesions were benign. In $2(6.25 \%)$ cases, the smears were inconclusive. Among the 25 lesions in the female patients, $13(52 \%)$ were malignant, 6(24\%) were benign and $3(12 \%)$ were inflammatory. In $3(12 \%)$ cases, the smears were inconclusive again. Out of 57 cases in total, $37(65 \%)$ were malignant, $15(26.31 \%)$ were benign, which includes 7 inflammatory lesions too. Benign lesions were more common in females than in males, whereas the malignant lesions had a slight male preponderance. (Table:2)

In the present study $8.77 \%$ cases were inconclusive due to either less cellularity, or more haemorrhagic aspirates in the background hindering the cytomorphology. Some may not have resemblance to any single diagnostic entity.

Majority of lesions were found in liver, with hepatocellular carcinoma being second most common entity following the most common entity of metastatic carcinoma. 1 case with neither qualifying for hepatocellular carcinoma nor for metastatic carcinoma was kept with poorly differentiated carcinoma. In 2 cases single diagnostic entity could not be assigned. (Table:3)

The second most common site was gall bladder with total of 8 cases. Out of total, adenocarcinoma of gall bladder outnumbered all with 5 cases followed by two inflammatory lesions of cholecystitis. (Table:3) 
Left iliac fossa masses and right iliac fossa masses were mostly malignant lesions. Gastrointestinal malignancies presenting as left iliac fossa masses were more (6 in number) than that as right iliac fossa masses. Benign lesions included one case each of inflammatory conditions and tuberculosis in right and left both fossas. (Table:3)

Among Retroperitoneal lymph nodes 1 case of non-Hodgkin's lymphoma 1 case of small malignant round cell tumour and 2 cases of adenocarcinoma of rectum were reported. However renal cell carcinoma was most malignant lesions of retroperitoneum with a total of 3 cases. Retroperitoneal sarcoma and inflammatory lesions were not that common.

Pathologies of ovaries and testis are commonly found pathologies in intrapelvic masses. 1 case of ovarian malignancy and 2 cases of seminoma were most commonly reported pelvic masses. Metastatic adenocarcinoma also presented with intrapelvic mass in one case.

Splenic and pancreatic pathologies were not that common.

Table 1:- Age and sex distribution of cases $(n=57)$

\begin{tabular}{|l|c|c|c|c|}
\hline \multicolumn{1}{|c|}{ Age } & Male & Female & Total & Percentage(\%) \\
\hline$<20$ & $02(6.2 \%)$ & $01(4.0 \%)$ & 03 & $5.3 \%$ \\
\hline $21-40$ & $04(12.5 \%)$ & $06(24.0 \%)$ & 10 & $17.5 \%$ \\
\hline $41-60$ & $18(56.2 \%)$ & $11(44.0 \%)$ & 29 & $50.9 \%$ \\
\hline $61-80$ & $08(25.0 \%)$ & $07(28.0 \%)$ & 15 & $26.3 \%$ \\
\hline & 32 & 25 & 57 & $100 \%$ \\
\hline
\end{tabular}

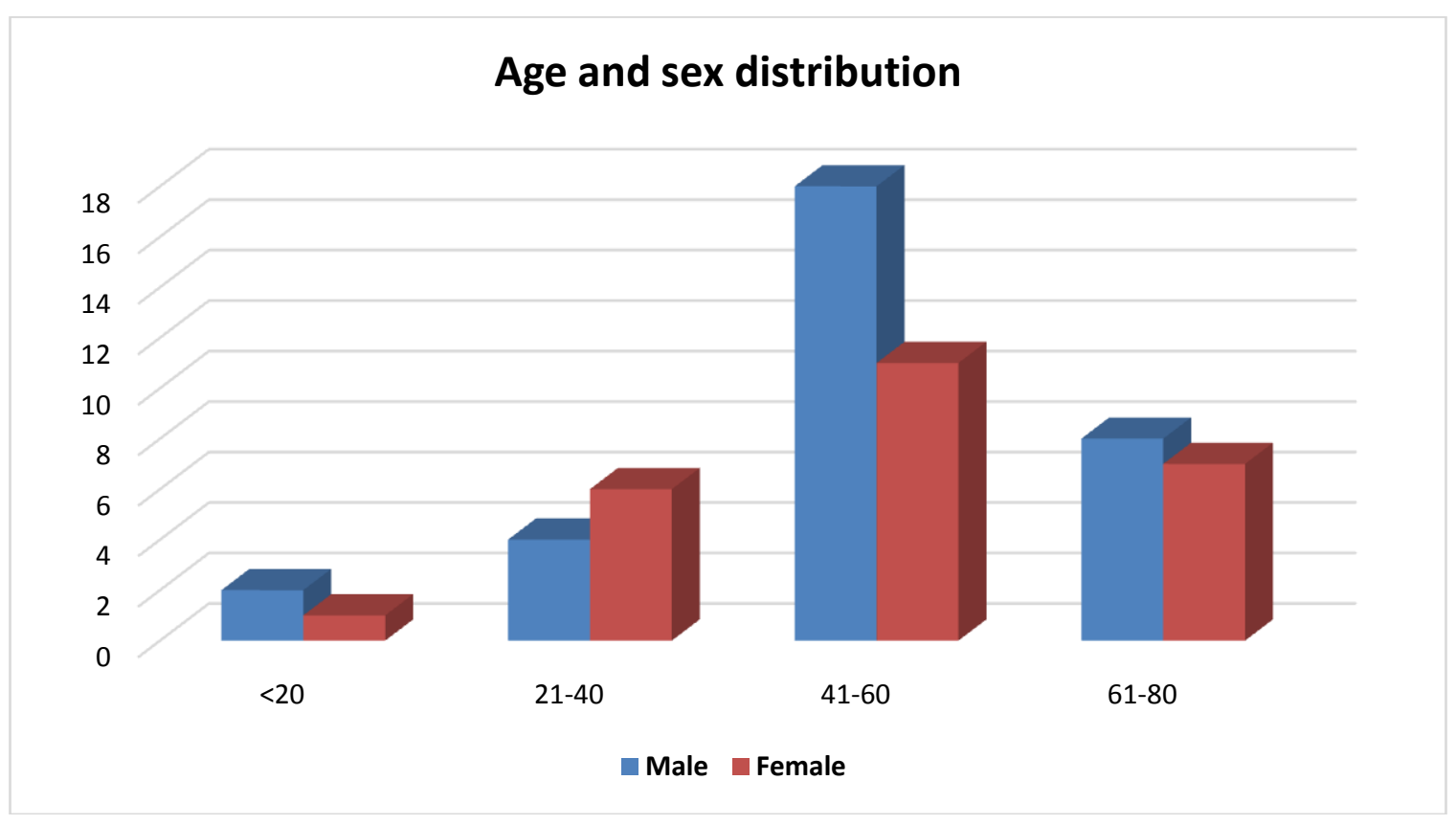

Table 2:- Cytological categories $(\mathrm{n}=57)$.

\begin{tabular}{|c|c|c|c|}
\hline & Male & Female & Total \\
\hline Benign & 6 & 9 & 15 \\
\hline Malignant & 24 & 13 & 37 \\
\hline Inconclusive & 2 & 3 & 5 \\
\hline Total & 32 & 25 & 57 \\
\hline
\end{tabular}




\section{CYTOLOGICAL CATEGORIES}

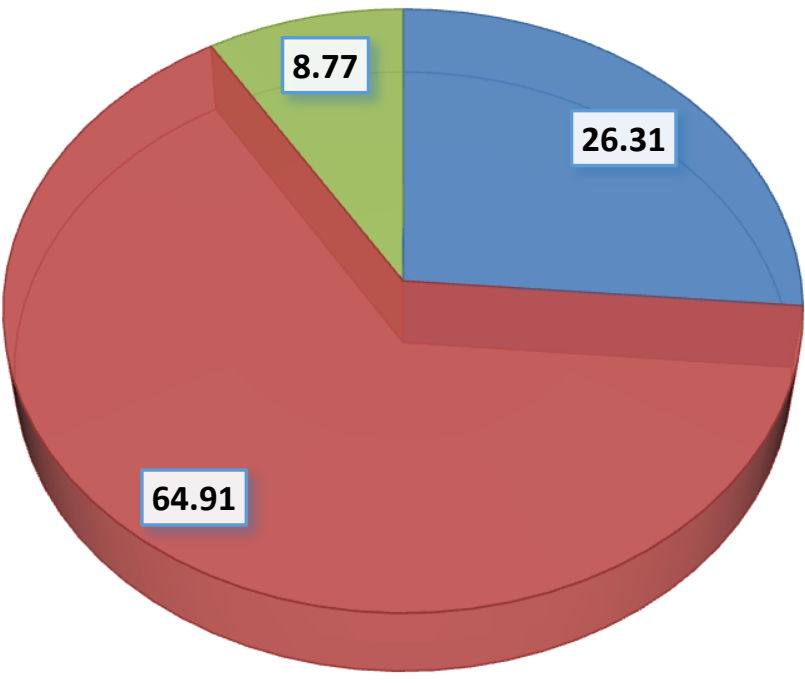

Benign

Malignant

Inconclusive

Table 3:- Cytological diagnosis of different lesions.

\begin{tabular}{|c|c|c|c|c|}
\hline & Benign & Malignant & Total & $\%$ \\
\hline Liver & $\begin{array}{l}\text { 1.Abscess -2 } \\
\text { 2.Diffuse parenchymal } \\
\text { disease-1 } \\
\text { 3.Cystic -1 }\end{array}$ & $\begin{array}{l}\text { 1.Hepatocellular carcinoma-3 } \\
\text { 2.Metastasis-5 } \\
\text { 3.Poorly differentiated } \\
\text { carcinoma-1 }\end{array}$ & 13 & 25 \\
\hline Gall badder & 1.Inflammatory-2 & $\begin{array}{l}\text { 1.Adenocarcinoma-5 } \\
\text { 2.Poorly differentiated } \\
\text { carcinoma-1 }\end{array}$ & 8 & 15.38 \\
\hline Right iliac fossa & $\begin{array}{l}\text { 1.Inflammatory-1 } \\
\text { 2.Tuberculosis-1 }\end{array}$ & 1.Adenocarcinoma -3 & 5 & 9.62 \\
\hline Retroperitoneum & 1.Inflammatory -1 & $\begin{array}{l}\text { 1. Renal cell carcinoma-3 } \\
\text { 2. Retroperitoneal sarcoma-1 } \\
\text { 3. Adenocarcinoma- } 2 \\
\text { 4. NHL-1 } \\
\text { 5. Malignant round cell tumour-1 }\end{array}$ & 9 & 17.30 \\
\hline Pancreas & Cysts -2 & & 2 & 3.85 \\
\hline Left iliac fossa & $\begin{array}{l}\text { 1.Inflammatory- } 1 \\
\text { 2.Tuberculosis- } 1\end{array}$ & 1.Adeno carcinoma- 6 & 8 & 15.38 \\
\hline Pelvic & 1.Inflammatory- 1 & $\begin{array}{l}\text { 1.Ovarian tumour }-1 \\
\text { 2. Seminoma }-2 \\
\text { 3. Metastatic adenocarcinoma- } 1\end{array}$ & 5 & 9.62 \\
\hline Spleen & 1.Abscess-1 & 1.Lymphoma -1 & 2 & 3.85 \\
\hline Total & 15 & 37 & 52 & 100 \\
\hline
\end{tabular}


Table 4:- Age and sex distribution of malignant lesion according to cell type.

\begin{tabular}{|c|c|c|c|c|c|c|c|c|c|}
\hline & \multicolumn{2}{|c|}{$<20$} & \multicolumn{2}{|c|}{$20-40$} & \multicolumn{2}{|c|}{$40-60$} & \multicolumn{2}{|c|}{$60-80$} & \multirow[t]{2}{*}{ Tota } \\
\hline Malignant lesions & male & $\mathrm{f}$ & $\mathrm{m}$ & $\mathrm{f}$ & $\mathrm{m}$ & $\mathrm{F}$ & $\mathrm{m}$ & $\mathrm{f}$ & \\
\hline Hepatocellular carcinoma & - & - & - & - & 2 & - & 1 & - & 3 \\
\hline Adenocarcinoma & 1 & - & 2 & 2 & 4 & 3 & 2 & 2 & 16 \\
\hline Metastatic adenocarcinoma & - & - & 1 & - & 2 & 2 & - & 1 & 6 \\
\hline $\begin{array}{l}\text { Poorly differentiated } \\
\text { carcinoma }\end{array}$ & - & - & - & - & - & 1 & - & 1 & 2 \\
\hline Renal cell carcinoma & - & - & - & 1 & 1 & - & 1 & - & 3 \\
\hline Retroperitoneal sarcoma & - & - & - & - & - & - & - & 1 & 1 \\
\hline $\begin{array}{l}\text { Malignant small round cell } \\
\text { tumour }\end{array}$ & 1 & - & - & - & - & - & - & - & 1 \\
\hline NHL & - & - & - & - & 1 & - & 1 & - & 2 \\
\hline $\begin{array}{l}\text { Mucinous } \\
\text { cystadenocarcinoma }\end{array}$ & - & - & - & - & - & - & - & 1 & 1 \\
\hline Seminoma & - & - & 1 & - & - & - & 1 & - & 2 \\
\hline
\end{tabular}

Table 5:- Age and sex distribution of benign and inflammatory lesion according to cell type.

\begin{tabular}{|l|c|c|c|c|c|c|c|c|c|}
\hline & \multicolumn{2}{|c|}{$<20$} & \multicolumn{2}{|c|}{$20-40$} & \multicolumn{2}{|c|}{$40-60$} & \multicolumn{2}{c|}{$60-80$} & f \\
\hline Benign lesions & $\mathrm{m}$ & $\mathrm{f}$ & $\mathrm{m}$ & $\mathrm{f}$ & $\mathrm{m}$ & $\mathrm{f}$ & $\mathrm{m}$ & $\mathrm{f}$ & $\mathrm{T}$ \\
\hline Abscess & 1 & - & 1 & - & - & - & - & - & 2 \\
\hline $\begin{array}{l}\text { Diffuse parenchymal } \\
\text { disease }\end{array}$ & - & - & 1 & - & - & - & - & - & 1 \\
\hline Cystic disease & - & - & - & - & 1 & - & 2 & - & 3 \\
\hline Tuberculosis & - & - & 1 & - & - & 1 & - & - & 2 \\
\hline Inflammatory & 2 & 1 & 1 & - & 2 & - & 1 & - & 7 \\
\hline
\end{tabular}

Table 6:- Sensitivity and Specificity.

\begin{tabular}{|c|c|c|}
\hline & \multicolumn{2}{|c|}{ Histology } \\
\hline FNAC & Positive & Negative \\
\hline Positive & 19 & 00 \\
\hline Negative & 01 & 01 \\
\hline
\end{tabular}



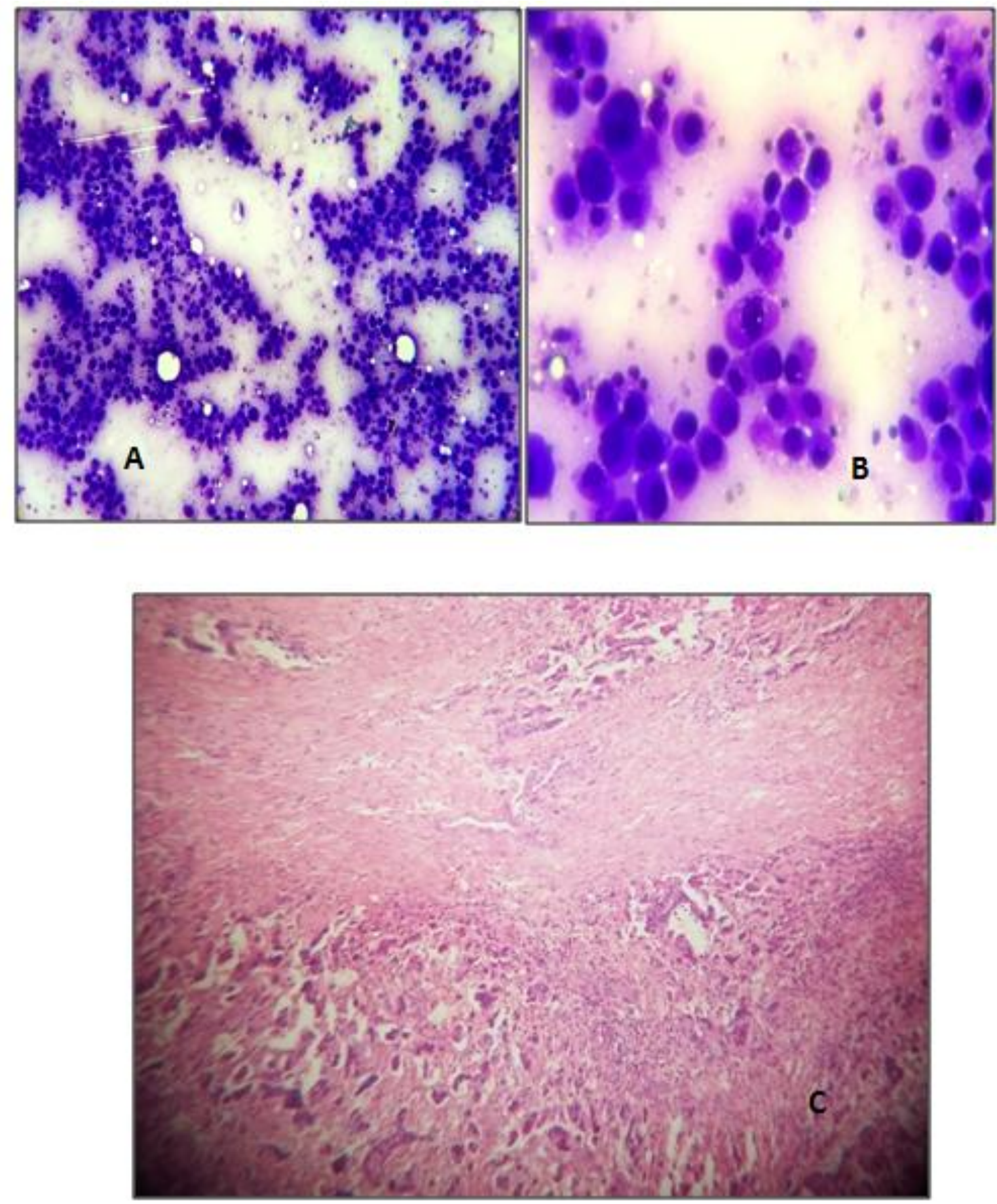

Figure 1:- Adenocarcinoma Gallbladder A. Giemsa [10x]; B. Giemsa [40x]; C. Histology [10x] H\&E. 

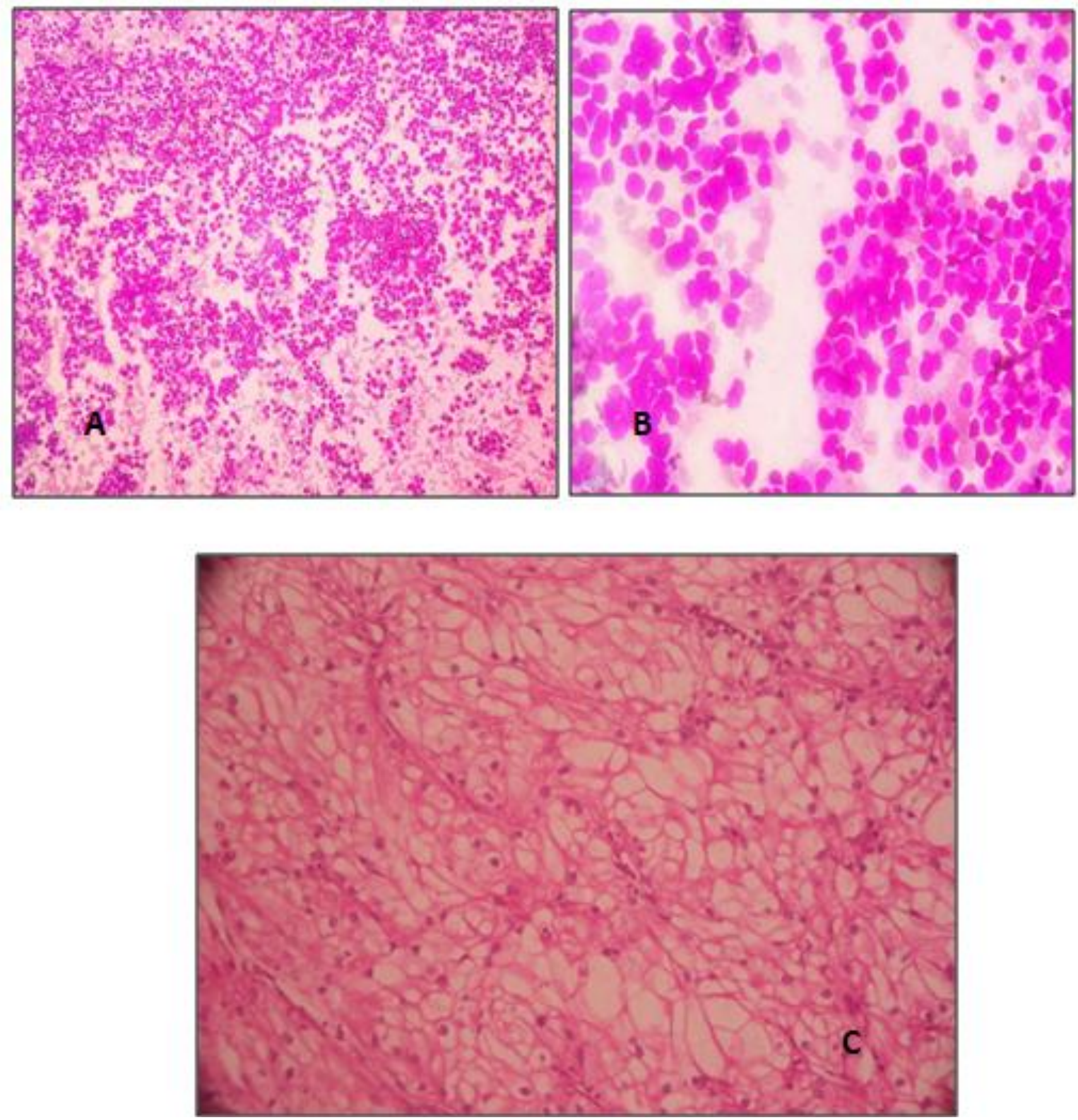

Figure 2:- Renal Cell Carcinoma, Clear Cell Type A. Giemsa [10x] ; B. Giemsa [40x] ; C. Histology [40x] H\&E. 

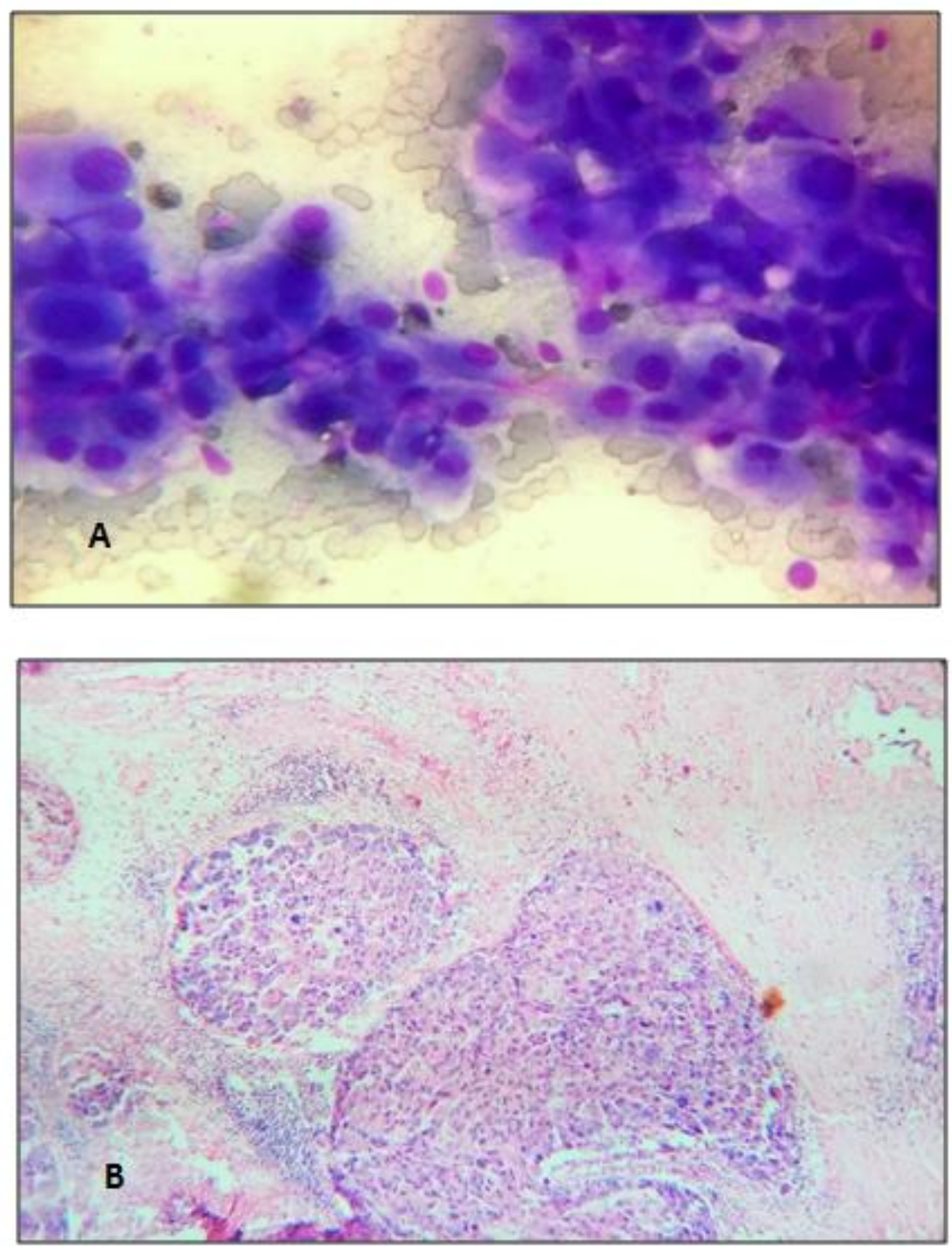

Figure 3:- Hepatocellular carcinoma A. Giemsa [40x]; B. Histology [10x] H\&E. 

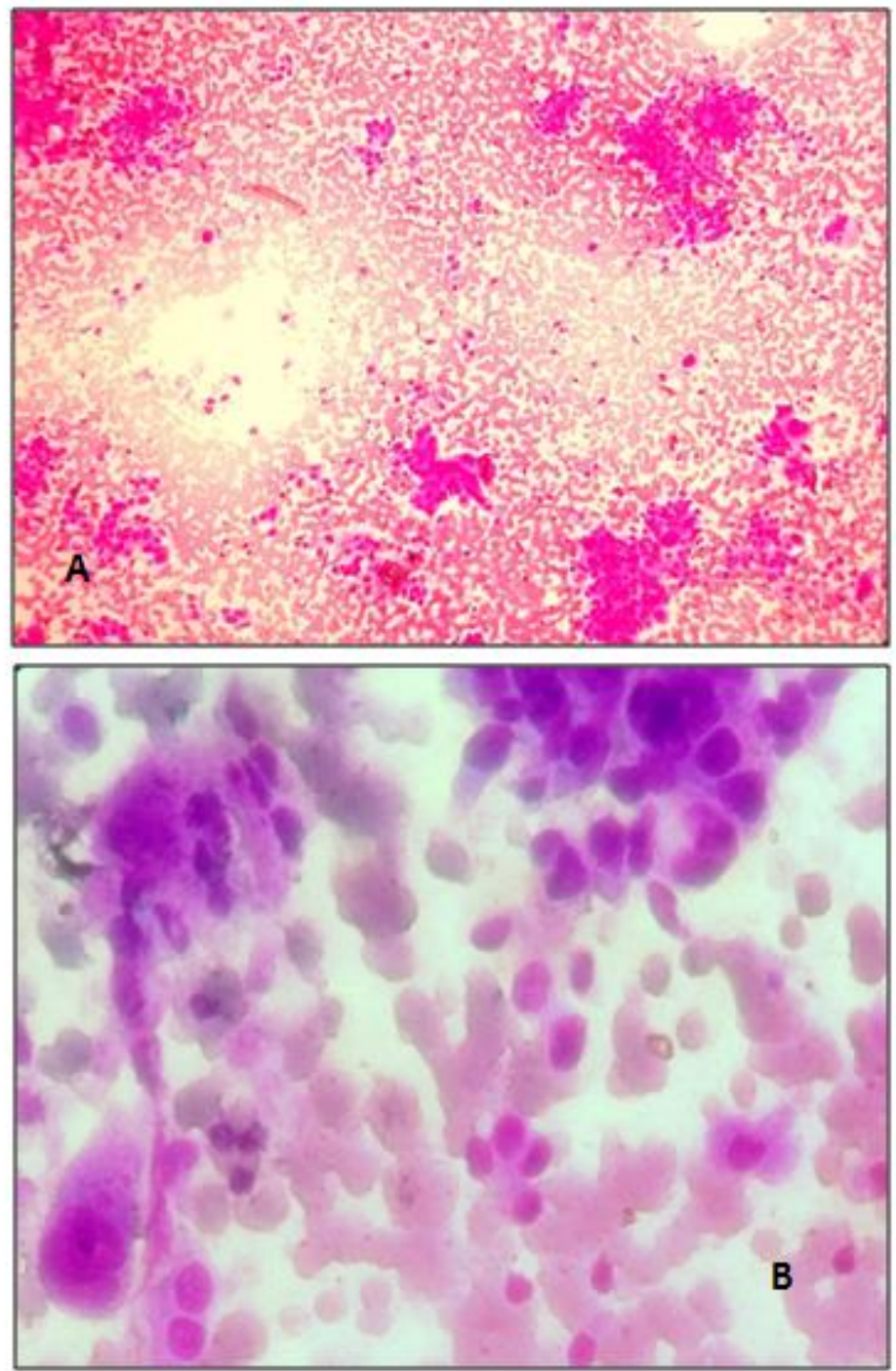

Figure 4:- Mucinous Cystadenocarcinoma Of Ovary (Giemsa) A. [10x] ; B.[40x].

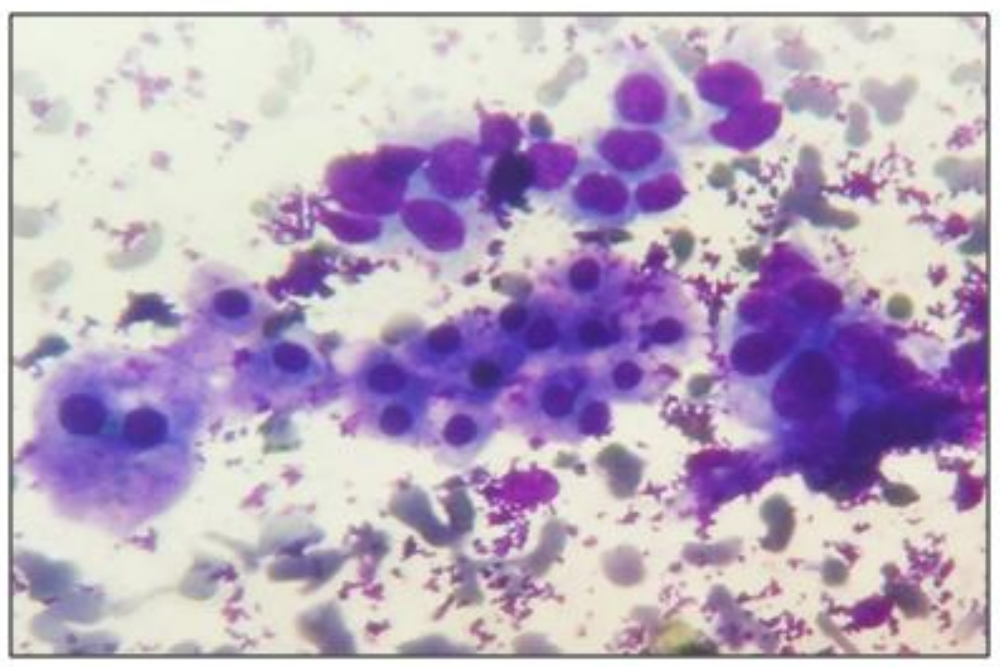

Figure 5:- Metastatic deposits in liver, smear shows few normal looking hepatocytes, [10x]; Giemsa. 


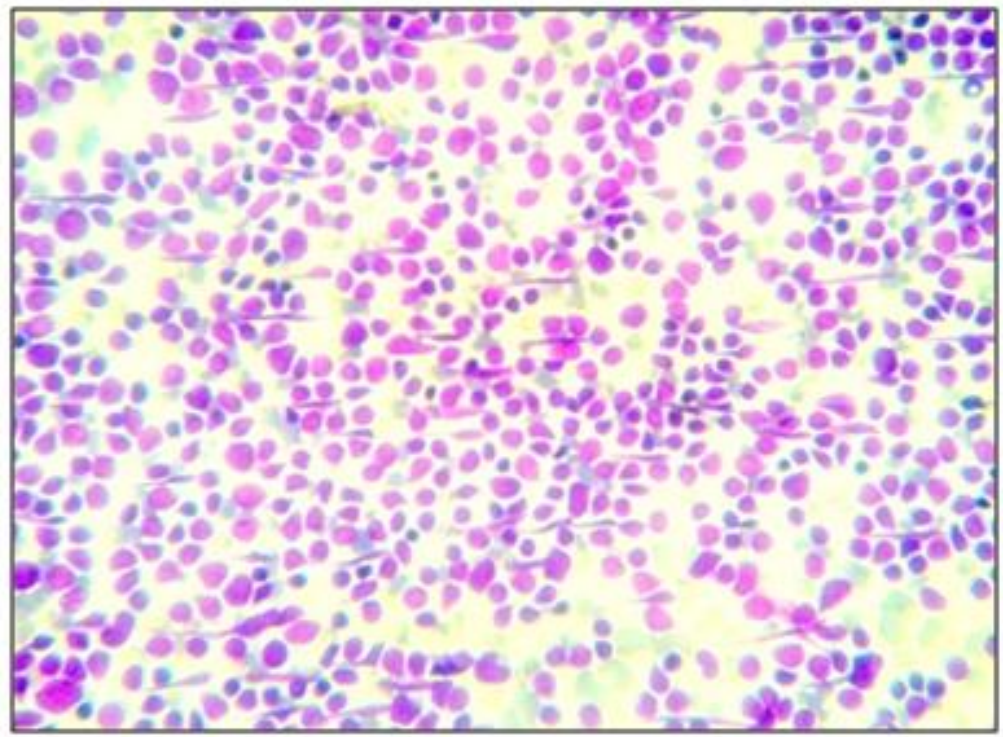

Figure 6:- Malignant Small Round Cell Tumor , [10x] ; Giemsa.

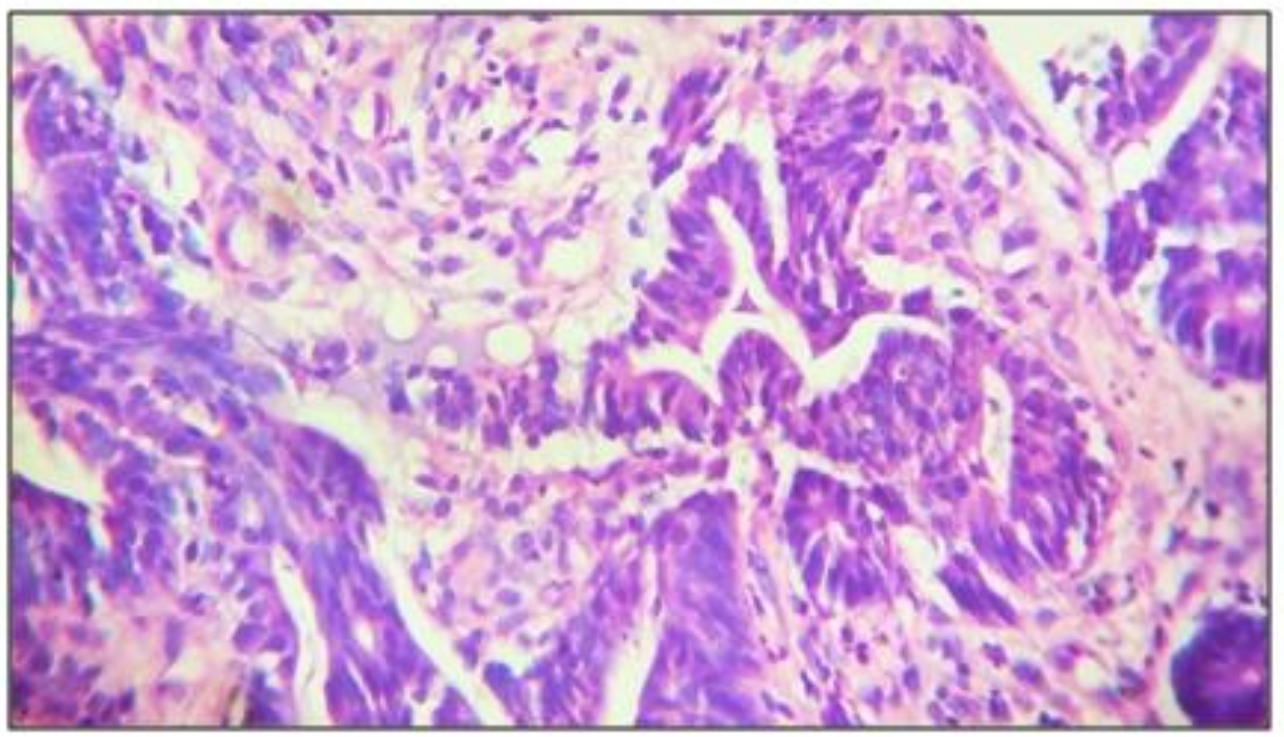

Figure 7:- Adenocarcinoma of sigmoid colon, (histology); [40x]; H\&E.

\section{Discussion:-}

The diagnostic confirmation is very important for rapid and appropriate planning of management of cases. To avoid exploratory laparotomy differentiation between benign and malignant disease is at times vital especially in advanced unresectable malignant cases. Ultrasound guided FNAC is a rapid, accurate, economical and a safe diagnostic procedure that can be used in various benign inflammatory and malignant lesions. As a diagnosis is rapidly available on FNAC, the appropriate medical or surgical therapies can be started earlier, thus avoiding unnecessary, expensive and often invasive diagnostic procedures. ${ }^{(9)}$

In the present study, diagnostic yield was calculated to be $91.2 \%$. this data was comparable to results found by Nautiyal S et al in 2004 with yield of $93.06 \%$. $^{(11)}$

In our study, age ranged from 2-78 years with majority of cases in age group of 41-60years. Similar data were obtained from various studies in past. ${ }^{(4,12,13)}$ Male to female ratio in the present study is found to be $1.3: 1$, with 
slight male preponderance. This is in accordance with results of Zawar MP et al (2007) ${ }^{[4]}$, Govind Krishna et al $(1993)^{[5]}$, Aftab A Khan et al (1996), ${ }^{[2]}$ and Ennis and Mac Erlean $(1998)^{[10] .}$

Malignant lesions comprising $64.91 \%$ of total are quite more than benign and non-neoplastic lesions with $26.31 \%$. Similarly, malignant lesions outnumbering benign ones were also reported by Sheikh et al (2000) ${ }^{(14)}$, SidhalingReddy et al $(2011)^{(15)}$, Sumana BS et al $(2015)^{(16) .}$

Liver was the common sites for FNAC in this study similar to those of Tuladhar AS et al(2012) ${ }^{(18)}$,Adhikari RC et al $(2010)^{(1)}$, and J Nobrega et al.(1994) ${ }^{(6)}$, In the liver, the most common malignant lesion was metastatic carcinoma which is comparable to the western literature. ${ }^{(3,8,17)}$ Second most common site of aspiration was gall bladder as found by Reyaz TA et al. (2016) ${ }^{(12)}$

In retroperitoneal masses renal cell carcinoma was most common malignant lesion of kidney. In a study by Adhikari $\mathrm{RC}$ et al (2010) ${ }^{(1)}$ same results were reported.

$8.77 \%$ cases were reported to be inconclusive. Data was comaparable to those of Sumana BS et al $(2015)^{(16)}$, SidhalingReddy et al (2011) $)^{(15)}$ and Tuladhar AS et al $(2012)^{(18)}$.

With histocytological correlation of 21 out of 57 cases, sensitivity and specificity for malignant lesions is found to be $95 \%$ and $100 \%$ respectively. ${ }^{(2,4,6,11,13,15)}$

\section{Conclusion:-}

For intraabdominal and intrapelvic masses, FNA cytology is more economical, simple and less cumbersome diagnostic procedure than laparoscopic procedures. Being assisted with USG guidance, it can be utilized for diagnosing ill-defined and deep seated lesions as well. Sharply delineated cytomorphology increases its diagnostic yield and also helps in categorization of malignant, benign and inflammatory lesions too. High sensitivity and 100\% specificity in diagnosing malignant lesions helps in selection of more appropriate surgical intervention as well.

\section{References:-}

1. Adhikari RC, Tuladhar A, Shrestha S, Sharma SK. Deep-seated thoracic and abdominal lesions: usefulness of ultrasound guided fine needle aspiration cytology, a 3 year experience. Nepal Med Coll J. 2010 Mar;12(1):20-5.

2. Aftab Khan A., Jan GM., Wani NA. Fine Needle Aspiration of Intraabdominal masses for cytodiagnosis. J. Indian Med Assoc 1996;94(5): 167-69.

3. Barbara A. Centeno. Pathology of liver metastases. Cancer Control.2006; 13(1): 13-24.

4. Dr. Zawar M.P., Dr. Bolde S., Dr. Shete S.S. Correlative study of fine needle aspiration cytology and histology in intra-abdominal lumps. SMJ 2007; 4

5. Govind Krishna SR., Ananthakrishanan N., Narasimhan R., Veliath AJ.Accuracy of Fine Needle Aspiration Cytology of Abdominal Masse without Radiological Guidance. Indian J. Pathol. Microbiol. 1993; 36(4): 442-52

6. Joao Nobrega and Guimaraes dos Santos. Aspirative cytology with fine-needle in the abdomen, retroperitoneum and pelvic cavity: a seven year experience of the Portuguese Institute of Oncology, Centre of Porto. European Journal of Surgical Oncology. 1994; 20: 37-42.

7. Joseph T., Ferrucci Jr. MD., Jack Wittenberg MD. CT Biopsy of Abdominal Tumors: Aids for Lesion Localization. Radiology 1978; 129: 739-744.

8. Juan Rosai, VJ. Desmet, GO. Nelson. Rosai and Ackerman's surgicalpathology. 9th ed. 2005; Mosby.

9. Langlois S Le P. Imaging methods for guidance of aspiration cytology. In: Orell SR, Sterrett GF, Whitaker D. Fine needle aspiration cytology, 4th ed.New Delhi: Churchill Livingstone:2005;31-40.

10. Mary Ennis G., MacErlean DP. Percutaneous Aspiration Biopsy of Abdomen and Retroperitoneum. Radiology 1980; 31: 611-16.

11. Nautiyal S., Mishra RK, Sharma SP., Routine and ultrasound guided FNAC of intra-abdominal lumps - A comparative study. Journal of Cytology 2004; 21 (3): 129-132.

12. Reyaz TA, Summyia F, Isma N, Nazia B, Adil S, Sameena K, Humaira B, Naila N, Ambreen B. USG guided fine needle aspiration cytology of intra-abdominal and pelvic masses in Kashmir: A study at tertiary care hospital. INTERNATIONAL JOURNAL OF MEDICAL RESEARCH \& HEALTH SCIENCES. 2016 Jan 1;5(4):169-75. 
13. S. Shamshad Ahmed, Kafil Akhtar, S. Shakeel Akhtar et al. Ultrasound guided fine needle aspiration biopsy of abdominal masses. JK Science. 2006; 8 (4): 200-204.

14. Sheikh M, Sawahney S, Dev P, al-saeed O, Behbehani A. Deep-seated thoracic and abdominal masses: usefulness of ultrasound and computed tomography guidance in fine needle aspiration cytology diagnosis. Australas Radiol 2000; 44: 155-60.

15. SidhalingReddy SK. Fine needle aspiration cytology of intra-abdominal lesions. Journal of Clinical and Diagnostic Research. 2011 Jun;5(3):551-8.

16. Sumana BS, Muniyappa B. Ultrasonography guided fine needle aspiration cytology with preparation of cell blocks in the diagnosis of intra-abdominal masses. Journal of clinical and diagnostic research: JCDR. 2015 Dec;9(12):EC08.

17. Svante R. Orell, Gregory F. Sterrett, Darrel Whitaker. Fine needle aspiration cytology. 4th ed. 2005; Churchill Livingstone.

18. Tuladhar AS, Adhikari RC, Shrestha S, Sharma SK, Pradhan S, Shrestha A, Tuladhar AG. Role of USG guided FNAC in diagnosis of abdominal and thoracic lesions. Nepal Medical College journal: NMCJ. 2012 Dec;14(4):271-4. 